\title{
Centrum a végeken - a Csíki Székely Múzeum szakmai tevékenysége
}

GYARMATI ZSOLT

\begin{abstract}
Csíki Székely Múzeum Hargita megye legnagyobb muzeális jellegú A közgyújteménye, fenntartója Csíkszereda megyei jogú város. Intézményünk az 1620-as években, Bethlen Gábor fejedelemsége idején épült, majd az osztrák uralom alatt katonai erőddé alakított Mikó-várban múködik. Rövid időközöket leszámítva, amikor különböző intézmények és hivatalok múködtek benne, a 20. század közepéig a várat a mindenkori hadsereg használta. Az 1970-es évek elején, nagyméretú restaurálás után itt kapott helyet az 1930-ban alapított múzeumi gyújtemény. A kiemelt fontosságú múemléképület hangulatos belső udvara nyaranta számos kulturális-szabadidős tevékenységnek ad otthont. Vegyes profilú intézményünk a klasszikus múzeumi gyújteményeket őrzi: történelem, néprajz, régészet, múvészetek, természettudományok. 26 fóállású és I 4 külső munkatársunk végez különböző szakmai feladatokat.

Küldetésnyilatkozatunk szerint a Csíki Székely Múzeum gyúiti, gondozza, kutatja és közzéteszi a csíki székelység kulturális örökségét. Nemzeti önazonosságunk tárgyi és szellemi hagyatékának hiteles őrzőjeként a Csíki Székely Múzeum erkölcsi, esztétikai értékeket, tudományos ismereteket közvetít. Részt kívánunk venni közösségünk fenntartható fejlesztésében, az életminőséo javításában. A múzeumot élő közösségi térként értelmezve szerepet vállalunk az oktatás és az igényes szórakoztatás területén.

Kiállításpolitikánkat a színvonal, az értékközpontúság és az egyensúly jellemzi. Évente szervezünk nagykiállításokat, melyek által úgymond házhoz hozzuk az összmagyar múvészeti és tudományos értékeket. A hét eddigi projektünkre összesen több mint 220 ooo látogató volt kíváncsi. Külön
\end{abstract}


kiemelem a székelyföldi múzeumok közti szakmai-baráti együttmúködés fontosságát, melynek keretében számos kiállítás, módszertani eszmecsere valósul meg.

Múzeumunk a tágabb értelemben vett kultúra, az igényes szórakoztatás helyszíne is kíván lenni. Rendszeresen adunk otthont táncháznak, filmfesztiválnak, színházi produkciónak, könnyúzenei koncerteknek, a Mikó-vár belső udvara a nyári időszakban a minőségi kikapcsolódás fontos színtere.

\section{Tudományos tevékenység}

A történelem-múvészettörténet részleg munkatársa, Muckenhaupt Erzsébet történész-muzeológus kutatási területe az erdélyi múvelődéstörténet. Ezenbelül mindenekelőtt a csíksomlyói ferences rendház egykori könyvtárának, nyomdájának, könyvkötő múhelyének monografikus feldolgozása foglalkoztatja. Ugyancsak tudományos tevékenységéhez tartozik az I802-ben lebontott, középkori alapítású csíksomlyói ferences templom és kolostor, valamint a középkori Mária-szobor történetének a kutatása. A csíksomlyói ferences könyvtár ősnyomtatvány-gyújiteménye az ország ötödik legnagyobb ősnyomtatvány-állománya. Muckenhaupt Erzsébet, kutatásai során János Pál nyugalmazott múzeumigazgatóval és Márk József ferences atyával együtt a csíksomlyói ferences kolostor refektóriuma falában a második világháború idején elrejtett I23 ősnyomtatványt és kéziratot tartalmazó könyvleletet talált. Elkészült a könyvlelet monografikus feldolgozása. Több megjelent tanulmány és kötet ismerteti a gazdag gyújteményt.

I5-18. századi történeti kötéseket, valamint I6-I8. századi nyomtatványokat vizsgált a somlyói könyvtár gyújteményében, elkészült a könyvek és a possessorbejegyzések leírása. Kolléganőnk sokat foglalkozott a Csíki Székely Múzeum Régi magyar könyvtár-gyúitteményével. Ebben a témában is több tanulmánya látott napvilágot, illetve összeállította a gyújteményi katalógust. A csíksomlyói ferences nyomda és könyvkötő múhely vonatkozásában elkészítette a múzeum, a székelyföldi plébániák és közintézmények, a gyulafehérvári Batthyaneum Könyvtár gyújiteményeiben, valamint magyarországi könyvtárakban (OSZK, MTA Könyvtára, a budapesti Magyar Ferences Könyvtár és Levéltár) feltárt és Csíksomlyón, a ferencesek nyomdájában megjelent nyomtatványok és bekötött könyvek azonosítását, leírását. A kutatás eredményeit az állandó múzeumi kiállítás és a múzeum által kiadott kiállítási katalógus tükrözi. 
Muckenhaupt kolléganőt hosszú éveken át foglalkoztatta a csíki nyomda első korszakának (I676-I70o) és a könyvkötő múhely első (kb. I630I675) és második korszakának (i676-kb. I700) a kutatása. Azonosította, leírta és publikálta a múzeum gyújiteményében és másutt őrzött olyan somlyói kötéseket, amelyek ebben az időszakban készültek, feldolgozta a múhely szerszámkészletét. A töredékkutatás folyamán a könyvtárakban és levéltárakban fennmaradt középkori latin kódextöredékek feltárását végezte. Elsőrendú feladata volt a fragmentumok és teljes kódexek tudományos feldolgozása, katalogizálása, közzététele. Folyamatban van a gyulafehérvári Batthyaneum Könyvtár ősnyomtatvány-gyúijteményének történeti kötései ceruzalevonatának elkészítése.

Markaly Aranka 20I4-től dolgozik a Csíki Székely Múzeumban mint történész-muzeológus. Az elmúlt évben elsősorban mútárgygyarapítással foglalkozott, azonbelül a tárgyak rendezésével, hozzájuk rendelhető adatlapok elkészítésével, ezek digitális másolatának rendszerezésével, valamint az adományhoz rendelhető hanganyag felvételével és vágásával. Több hagyatékot is feldolgozott, mint például Miczi Mihály, Nedelka Katalin, Kőszegi Piroska, Keresztes Gábor adományait. Mindezek fontosak a város története szempontjából is, hisz az adományozók és családjuk általában kiemelkedő szerepet töltöttek be a város I9-20. századi életében. Közben folyamatosan kutatást végez Csíkszék I6-I7. századi történetét illetően, kiemelten Csíkszeredára vonatkozóan. Kutatását a készülő várostörténeti kiállításhoz hasznosítjuk, ezért rendszeresen részt vesz a gyúléseken, szakmai tanácsokkal segíti a készülő kiállítás rendezőit. 2015 decemberében a I7. századi csíkszélki nemességről tartott előadást a Múzeumi esték nevú rendezvény keretében. Jelenleg a múzeum által őrzött I6-17. századi nemesi okleveleket írja át, forrásközlésre készíti elő, mely a 20I6-os múzeumi évkönyvünkben fog megjelenni. Mindezek mellett Muckenhaupt Erzsébet múvelődéstörténész-muzeológussal együtt mostanra sikerült rendeznie a Domokos Pál Péter-hagyatékot, amelyhez szintén adatlapok és digitális másolatok készültek. Ez a hagyaték körülbelül 60 dossziényi helytörténeti adatot, fotót, rajzot tartalmaz főként Csíkszékre, Gyergyószékre vonatkozóan. Az idei évben közösen hozzálátnak a csíkszéki deliberátumok, vizitációs jegyzékek átírásának, forráskiadványként való előkészítésének.

Ladó Ágota 2014 őszétől dolgozik a Csíki Székely Múzeumban, ezzel párhuzamosan pedig a Babeș-Bolyai Tudományegyetemen a Kolozsvári Magyar Történeti Intézet Történelem, civilizáció, kultúra doktori iskolájának II. éves hallgatója. Kutatási témája Csíkszereda városfejlódése I876-tól az elsó világháborúig. Bekapcsolódott az új várostörténeti kiállítás előkészüle- 
teibe, fóként a néhány éve megkezdett módszeres mútárgygyújtési munkálatokba. Adományok rendszerezésén és leltárba vételén dolgozott, többek között olyan nagy múltú csíkszeredaiak hagyatékán, mint a Filep-Hirsch vagy a Lux családok. A mútárgygyarapítás érdekében több ízben vett részt helyszíni gyúitéseken is, melyek során kiürült polgári lakóházból, leégett gyárépületből sikerült kimenteni az elmúlt korok, letúnt rendszerek néhány tárgyi emlékét.

A készülő várostörténeti kiállítás két századfordulós tematikájú termének felelőseként kutatásai mellett folyamatosan figyelemmel kíséri a különböző kiállitásrendezési trendeket, valamint az ezzel kapcsolatos szakirodalmat, rendszeresen részt vesz a tematikus megbeszéléseken, illetve konzultál az egyes résztémák szakértőivel. A kiállításrendezési munkálatok kezdeti fázisában megtörtént a legjelentősebbnek tartott I9. század végi-20. század eleji események tematizálása. 2016 első felében az így körvonalazott témák bemutatási lehetôségeinek kidolgozása, valamint az egyes témákhoz rendelt tárgylisták összeállítása zajlik. Heti rendszerességgel találkozik helyi adatközlőkkel, régi csíkszeredai családok leszármazottaival, és az oral history módszereivel olyan városi történeteket rögzít, melyek mára már kikoptak a kollektív emlékezetből. A konzultációk során sikerült feldolgozni az egykori Vár (mai Petőfi) utca házainak, egykori lakóinak, kereskedéseinek, vendéglóinek történetét. Megtörtént az épülethomlokzatok jelenlegi állapotának dokumentálása, valamint majdnem száz darab, a 20. század különböző korszakaiból származó térkép részleges feldolgozása is. Jelenleg a Kossuth utcával kapcsolatos történetek rögzítése zajlik.

20I4-ben közremúködött a Múzeumi esték előadás-sorozat elindításában és megszervezésében. A havi egy alkalommal sorra kerülő ismeretterjesztő, tudomány-népszerúsító rendezvény célja átláthatóbbá és érthetőbbé tenni a múzeumban folyó munkát, közelebb hozni egymáshoz a múzeumi szakembereket és a kiállítások látogatóit. Szeretnénk felhívni a figyelmet helyi értékeinkre, városunk történeteire, valamint felkelteni az érdeklödést a készülő várostörténeti kiállítás iránt. Ladó Ágota az elmúlt év folyamán több konferencián is tartott előadást építészettörténeti kutatásairól, valamint azokról az örökségvédelmi programokról, melyekben részt vesz. Emellett a csíkszeredai városnapok keretében megnyitotta Kelemen Albert Megrajzolt székelyföldi értékeink címú grafikai kiállítását. 2015. szeptember 9-20. között részt vett a Cultural Heritage without Borders elnevezésú svéd alapítvány által a koszovói Mitrovicában megrendezett nemzetközi örökségvédelmi-muzeológiai szakképzésen, november folyamán pedig Bécsben folytatott várostörténeti, módszertani kutatásokat. 
Kósa Béla múvészettörténész a múzeumunknak helyet adó Mikó-vár építészettörténeti helyszíni kutatását a 2008-2013 közötti időszakban valósította meg. Ennek köszönhetóen több lappangó múrészlet került napvilágra, illetve elkészült az épületegyüttes periodizációja. A I7. századi épületrészeken előbukkant megközelítőleg $70 \mathrm{~m}^{2}$ festett homlokzati díszítő vakolat, több, mint 50 lőrés, egy belső lépcsőház, az udvari loggia lenyomata, a hozzá tartozó faragott pillérek, fejezetek és lábazatok, mellvéd- és párkánytöredékek, egykori nyílások faragott kerettöredékei, az egykori felvonóhíd emelőszerkezetének részletei. Kósa azonosította a két egykori kápolna eltúnt részeinek a lenyomatát, a pincerendszerek I7. századi részeit, a helyiségek egy részének eredeti fedését. Az épületegyüttes I7. század végi, használaton kívüli korából falfirkákat, míg az azt követó úijáépítési korszakból az erődítési átalakításokat, későbbről a I8-I9. századi laktanya életét szemléltető grafikákat talált. Kutatásainak köszönhetően viszonylag jó rálátásunk lett az épületegyüttest érintő különböző átalakításokra, átépítésekre, melyeknek tudományos közzététele folyamatban van.

A készülő várostörténeti kiállításunkra 20I3-ban meghirdetett mútárgygyarapítási akciónk egyik első adománycsoportja a csíkszeredai egykori Fekete Sas gyógyszertár hagyatéka, ezen anyag gondozása és tudományos feldolgozása szintén kollégánk feladata. Az adományegyüttest kitevő mintegy 254 tétel másfél esztendő alatt I4 alkalommal három személytől (Boros Ibolya, Ajtony Gábor, Ajtony Pál), három módon (eredeti adományozása, digitális másolat adományozása, eladás) gyúlt be. Csíkszereda első, bizonyíthatóan múködő polgári gyógyszertárát létezésének I06 esztendeje (I843-1949) alatt, illetve hozzá köthető tárgyait és személyeit tágabb értelembe vett létezése alatt (I837-20I4) rengeteg viszontagság érte. Kiemelnénk az I849-es lefoglalását, a két világháborúból az i9I6-os román betörést és az I944-es szovjet bevonulást, az I949-es államosítást, az I963-as elköltöztetést, valamint az utolsó épület I984-es lebontását.

Ezek és az ehhez hasonló, a gyógyszertár tágabb értelemben vett életében törést okozó események minden tragikumuk mellett hozzájárultak ahhoz is, hogy az a kevés, ami maradt, őrzői számára még inkább menekítendő és őrizendő legyen. A gyújteménybe tartozó tárgyak I852-I984 közöttiek, és pár főbb csoportra oszthatóak: a I9. század második felének gyógyszertári naplói, könyvelései, fókönyvei; az utolsó két tulajdonos család (Gőzsy és Ajvász-Ajtony) személyeihez kapcsolódó iratok; a gyógyszertár egykori officínájának berendezése (bútoregyüttes és felszerelés); a további helyiségek (laboratórium, raktár) egykori felszerelésének töredékei; a gyógyszertár egykori reklám- és arculatanyaga; az utolsó (I934-I984) 
épület történetéhez kapcsolódó emlékanyag. Ezen anyag tudományos feldolgozása és a készülőfélben levő várostörténeti kiállításunkon való hasznosítása és bemutatása folyamatban van, a csíki gyógyszerészet történetének első fél évszázadát bemutató tanulmány pedig az idei évkönyvünkben lát napvilágot.

A múzeum régészeti osztályán két muzeológus dolgozik. Botár István régész 2007-2015 között több templomban végzett feltárásokat. 2007-ben Csíkmenaságon egy egyenes záródású Árpád-kori és egy sokszögzáródású szentély alapfalait tárta fel a jelenlegi templom belsejében. Karcfalván 2OII-ben sikerült igazolni, hogy a templom felmenő falai középkori eredetû́ek, és a szentélynél korábbiak. A csíkszentimrei Margit-kápolna félkörives szentélyét 20I2-ben dokumentálta, és ugyanebben az évben kerültek elő a pogányhavasi (Csíkszépvíz) Szent László-kápolna alapfalai is. Szintén középkorinak bizonyultak a csicsói egykori kápolna, ma plébániatemplom hajófalai is. 20I4-ben sikerült igazolni azt a 2005-ös feltevést, hogy a csíkmindszenti plébániatemplom Árpád-kori szentélye egyenes záródású, illetve hogy volt egy korábbi sekrestyéje is. 2015 nyarán sikerült dokumentálni a csíkszentmártoni templom gótikus szentélyét és korábbi hajójának alapfalait is.

Az egyházi épületek kutatása mellett Botár István több népvándorlás és középkori településen vezetett ásatásokat. 2007-2008-ban Kotormányban tárt fel Árpád-kori és I4. századi objektumokat. 2009-ben Poklondfalván (Csíkszentkirály) ez ezredfordulóra keltezhető idegen népesség leletanyaga és I3. századi bécsi denárral keltezett leletek kerültek elő. A korszak legfontosabb kutatásai közé sorolhatók a Fodor-kerti ásatásai (2OII, 20I4-20I5.), ahol két Árpád-kori lakóházat tárt fel, de itt került elő az első csíki gót (4. század) és az első szláv (6-7. század) földbe mélyített, kőkemencés lakóház is.

Szintén ebben az időszakban kezdődtek a középkori udvarházak feltárásai. Ezek közül Botár István a csíkkozmási Becz-kúria (2009-20II) és a vacsárcsi úgynevezett Sándor-kúria (20I2-20I3) területén tárta fel a középkori épületek alapfalait. Ugyanezeken a lelőhelyeken talajradaros vizsgálatok segítségével tisztázták a föld alatt lappangó alapfalak kiterjedését. $\mathrm{Az}$ ásatások mellett kollégánk több régészeti felügyeletet (ivó- és szennyvízcsatornák, gázvezetékek, építkezések) is ellátott ebben az időszakban Csíkszentimrén, Csíkkozmáson, Csíkszentgyörgyön, Csíkszentléleken, Csíkszentkirályon, Zsögödön, Csicsóban. Az ásatási idények előtt és után több falu határában és belterületén végzett terepbejárásokat a települések középkori előzményeinek és ezek kiterjedésének felderítése érdekében. 
20IO-ben indult a népvándorlás kori, ezenbelül a gótok régészeti hagyatékának módszeresebb feltérképezése. Botár Attila ezzel kapcsolatos ásatásai a szentmihályi új óvodánál (20I0), a szentimrei Kúria utcában (2008, 20IO), a csíksomlyói árvaháznál (2OII) és a szintén csíksomlyói Fodor-kertben zajlottak (2OII, 20I4-20I5). 20I3-ban szervezte meg a csíki középkori templomok és lelőhelyek jelentős részét érintő légifotózást, illetve ugyanez év tavaszán a csíki középkori várak topográfiai felmérésében is részt vállalt.

A fenti régészeti tevékenységek mellett 20I2-től Botár István aktív résztvevője az OTKA által támogatott erdélyi dendrokronológiai kutatásnak, amely során közel másfél száz erdélyi múemlékből (templomok, tornyok, kastélyok, udvarházak, illetve faberendezések: oltárok, stallumok, kazettás mennyezetek stb.) gyújtött famintákat, és keltezte az építési periódusokat. A tölgy- és jegenyefenyő-kronológiák érvényessége ma a I3-20. század közötti időszakot fedi le.

Botár István 20I5-ben védte meg az ELTE-n Csík középkori településtörténetét feldolgozó régészeti disszertációját.

Darvas Loránd régész kutatásainak központi témáját a késő középkori székely társadalom anyagi múveltségének vizsgálata képezi. Ezen cél érdekében részben leletmento, részben tervszerú régészeti kutatásokat végzett a Kőrösi Csoma Sándor utcában (I4. századi háromosztatú lakóház feltárásával), Csíksomlyón a Fodor-ház udvarán (I4. századi lakóházrészlet kutatása), valamint Csíkszentkirályon a Kőoldal nevezetú dúlőben (az Andrássy család csíkszentkirályi udvarháza részleteinek feltárása). Ezen régészeti kutatások eredményeként egy viszonylag jó keresztmetszet rajzolódott ki a középkori, késő középkori csíki udvarház fejlődéséről, valamint a köznépi és nemesi társadalom anyagi múveltségéról.

Egy másik fontos kutatási témát képez a Csíki-medence egyházi épített örökségének kutatása. Ezen témakörben az elmúlt időszakban leletmentó kutatásokra került sor a csíksomlyói ferences kolostortemplom sekrestyéjében, valamint a kolostorépület közvetlen környezetében, illetve a csíkszentléleki római katolikus plébániatemplom cintermében. Leletmentő kutatásokat végzett továbbá olyan régészeti lelőhelyeken is, melyek nem képezik a szakmai érdeklődése központi témáját, azonban nagyon fontosak a Csíki-medence történeti múltjának feltárásában: Csíkdelnén az Inczék hídja (késő vaskori, La Tène-település), Csíksomlyón a Fodor-ház, valamint a Domokos Pál Péter Árvaház környezete (császárkori 4. századi, gót település részletei). A csíkszentléleki római katolikus plébániatemplomnál felújítást megelőző régészeti kutatásokat végeztünk. A 2015. őszi leletmentés 
során több építkezési periódust tudtunk meghatározni, valamint feltártunk 8 sírt, illetve sírrészletet. Darvas azonosított egy I2-I3. századi román kori periódust, egy I4. századi kora gótikus periódust, valamint egy I5-I6. századi késő gótikus periódust. A feltárt temetkezések közül két sír a legelső, I2-I3. századi templomhoz igazodott, mivel azonban melléklet nélküli sírok, keletkezésük pontos korát még nem tudni. Remélhetőleg a közeljövőben Cı4-es vizsgálatokat tudunk végeztetni a vázakból, és akkor megtudjuk az eltemetésük idejét, mely által postquem keltezni tudjuk a korai templomot is.

Szabó András muzeológus, a Zsögödi Nagy Imre-hagyaték kurátora az utóbbi években befejezte a Napfaragók I-VIII. kötetre tervezett monográfiasorozat első két kötetének a kéziratát: Napfaragók I/Auspicii - Kezdetek és Napfaragók II/Auspicium verum - Igazi kezdet. Az öt évet magában foglaló kutatói tevékenysége részfeladatai a következőképpen összegezhetők: budapesti, bukaresti, csíkszeredai, kolozsvári, marosvásárhelyi könyv-, adatés levéltárakban található iskolai értesítők, tanulmánykötetek, napi- és hetilapok, folyóiratok átolvasása, kivonatolása és teljes cikkek kimásolása. A monográfiasorozat elkészítésével a szerző a következőképpen fogalmazza meg célját:

„Szándékomban, a következő elképzelés vezérelt: ha a csíkszeredai képzőmúvvészet szerves része a nagy magyar múvészetnek, majdnem hiába az, ha személyiségeit, tényeit, eseményeit e tudományág csak múvészenkénti - kiről több, kiről kevesebb - részletben, adategyedként ismeri, nem pedig folyamatában, lehetőleg összefüggései szerint. Úgy éreztem, ha nem állítom össze ezt a könyvsorozatként szerkesztett adattárat, tudományosságunkat magam fosztom meg egy szakismerettártól, s azzal nemcsak megnehezítem a szaktársak dolgát, hanem, talán kárt is okozok magyar múveltségünk ügyének. Könyvsorozatom jelentőségét elsősorban helytörténetinek tekintem, ezért nemcsak múvészettörténészeknek, hanem a csíki, a székelyföldi, az erdélyi - s minden magyar - közembernek szánom. Szerezzenek átfogó tudomást rólunk, csíki múvészekrool! Rólunk, akik úgy ismerjük és ismertetjük meg a világot, hogy látva látjuk, látványába beleéljük magunkat, és megörökítjük azt, illetve szófordulat-hagyományainknak megfelelően lelkünk rezzenéseiről képet írunk, ahogyan: hegyet hágják, vadat úzik, pénzt olvassák, asszonyt veszik, táncot járják, a szót ejtik, a bajt vívják, képet írják... tartották még a klásszikus üdőkben. Mindent - majdnem mindent, sokat - összegyúijteni az összhang érdekében!”

A restaurátor részleg személyi és infrastrukturális fejlesztése a Csíki Székely Múzeum szakmai tevékenységének egyik prioritása. Múzeumunk- 
ban papír, bőr, fa, fém, kerámia és textília alapanyagú tárgyak konzerválása, restaurálása zajlik. A papírrestauráló múhely vezetője, Benedek Éva többek között I3-20. századi kéziratos és nyomtatott töredékek (unikumok és hungarikumok), könyvek (ezek között ősnyomtatványok), történeti kötések, pergamen és papír oklevelek, okiratok stb. restaurálását végzi. A könyvrestaurátor munkakörébe tartozik a tárgyak szükség szerinti fertőtlenítése, anyagvizsgálata, fotódokumentációja, a restaurálási módszerek megállapítása. Ezenbelül fontos: esetleges oldódó tinták rögzítése, helyi folt tisztítása, száraz és nedves kezelések elvégzése, semlegesítése, a papír enyvezőanyagának pótlása, a hiányok kiegészítése, az információk megerősítése, kasírozása, a kötésproblémák megoldása, a könyv eredeti formába való viszszaállítása. Elkerülhetetlen a restaurálási etika elvének betartása: a mútárgy általános állapotának javítása, a dokumentum igazi jellegének, funkciójának megtartása, az eljárások, anyagok reverzibilitásának (visszafordíthatóságának) figyelembevétele, az eredetihez legjobban hasonlító anyagok használata. Múzeumunk arra törekszik, hogy a konzervált, restaurált tárgyak egy részét közszemlére bocsássa, biztosítva a szakmai munka transzparenciáját. Ennek jegyében készült el a Megmentett szakrális kincseink c. restaurálási kiállítás, háromnyelvú kiegészítő magyarázó táblával, összekötve egy kisfilmmel, mely a könyvek, oklevelek, fa- és textilalapú tárgyak restaurálásának mozzanatait mutatja be.

A kiállított tárgyak közül a legértékesebbek: I3. századi liturgikus pergamenkódex-töredék, a Breviarium notatum, a I5. századi papírkódextöredék, a Psalterium, az ugyancsak I5. századi pergamenkódex-töredék, az Antiphonarium, az I626-ban Bécsben nyomtatott első katolikus bibliafordítás, a Káldi-féle Szent Biblia, az I660-I66I-ből származó, Szenci Kertész Ábrahám által Várad-Kolozsváron kiadott református Szent Biblia. A restaurált egyházi múkincsek, az oltárképek, korpuszok, szobrok közül említést érdemel a 15. századi Mária megkoronázása c. oltárkép, a I8. századi aranyozott ferences szárnyas feszület, a I8-I9. századi Szúz Mária a kis Jézussal körszobrok. Ugyancsak jelentős szellemi kincsnek számítanak a görögkeleti valláshoz tartozó, fára festett, I7. századi ikonok, Jézus bevonulása Jeruzsálembe, a Három királyok imádása. A restaurált múkincseket a konzerválási követelményeknek megfelelően, zárt tárolószekrényben, a fény, a hőmérséklet, a relatív páratartalom elleni védelem elóírásait betartva állítjuk ki.

Lázár Levente restaurátor 20I4-től dolgozik múzeumunkban. Munkájának egy részét a várostörténeti kiállításra beérkezett tárgyak konzerválása jelenti. Ennek a munkának egy nagyobb volumenú részét a múzeum által megvásárolt néhai Fekete Sas gyógyszertár fennmaradt bútorzatának kon- 
zerválása és restaurálása képezi. Ezt a munkálatot egy átfogó történeti és készítéstörténeti tanulmány előzte meg, mely a Csíki Székely Múzeum 20I5-ös évkönyvében látott napvilágot. A konzerválási és restaurálási munkálatok, valamint az állományőrzési feladatok minőségi ellátásához a restaurátormúhely fejlesztése is szükségszerúvé vált. Ez a folyamat így a 2015. év folyamán is folytatódott, melynek keretében különböző szerszámgépek és múszerek beszerzése mellett a múhely anyagkészlete is bővült. 2016 kiemelt jelentőségú feladata a múzeum raktárainak felmérése és a tárolási körülmények javítása. A raktárak felmérését a helytakarékos és mútárgycentrikus tárolás érdekében egy kisebb átrendezés követte, amelyet Tövissi Júlia és Lázár Levente új tárolóegységek tervezésével, beszerzésével, esetenként elkészítésével és a tárgyak elhelyezésének újragondolásával oldott meg.

A Csíki Székely Múzeum múzeumpedagógiai tevékenysége közel egy évtizedet tudhat maga mögött. A múzeumpedagógiai foglalkozások széles skálájába tartoznak az időszakos és állandó kiállításokhoz kapcsolódó múzeumpedagógiai órák, a jeles napokhoz fúződő családi napok, az évközi és nyári vakációs múzeumi szaktáborok, a fogyatékkal élő fiataloknak és speciális igényú gyerekeknek tartott foglalkozások, valamint az egyes országos (Iskola másként hét) és nemzetközi rendezvények múzeumi térben való megvalósítása. A múzeumi órákra fóképp a Csíki-medence iskoláiból, a nagyméretû́ időszakos kiállításainkra pedig Erdély magyar tannyelvú iskoláiból is érkeznek diákok. A vakációs táborokban évente több mint száz gyerek fordul meg. A részvételi arány szempontjából a tavalyi évben is a Big Draw, a Nagy rajz nemzetközi esemény bizonyult a legsikeresebbnek. A Márton Árpád 75 jubileumi kiállításhoz kapcsolódó Nagy rajz 2015ben közel I5O érdeklődőt vonzott.

A 20I5-ös év a múzeumpedagógiai fejlesztések éve volt a Csíki Székely Múzeumban. A néprajzi kiállítás egyéni családos látogatókat célzó múzeumpedagógiai eszközfejlesztését követte az erdélyi múzeumi szférában egyedülálló múzeumpedagógiai foglalkoztatótér kialakítása, amely korszerú környezetet biztosít a múzeumi tanuláshoz.

$\mathrm{Az}$ infrastrukturális fejlesztéseken túl új célcsoportok felé is nyitott az intézmény. A csíkszeredai Authelp Egyesület által múködtetett Puzzle Oktatási Központ pedagógusaival együttmúködve tavaly először fogadtunk autizmussal élő gyermekeket a múzeumban. A speciális igényú fiatalok bevonásának következő állomását a Szent Ágoston Foglalkoztató Központ fogyatékkal élő fiataljai számára szervezett egyhetes nyári múzeumi tábor képezte.

A tavalyi év ugyanakkor a székelyföldi múzeumpedagógia szakmai 
együttmúködésének kezdetét jelentette. A Csíki Székely Múzeum szervezésében sor került a székelyföldi múzeumpedagógusok első múhelytalálkozójára, amely lehetóséget adott a tapasztalatcserére, valamint az együttmúködés, a közös cselekvés lehetőségeinek a megfogalmazására. A múhely kézzel fogható eredménye a MúzeumPont Facebook-oldal létrejötte, amelyen a székelyföldi múzeumok aktuális múzeumepedagógiai kínálata követhető. A pók, oldalunk kabalája arra ösztönözi a múzeumbarát közönséget, hogy hálózatban gondolkodjanak a székelyföldi múzeumokról. 